\title{
Implementing Collaborative Writing to Teach Writing for Non-English Major Students
}

\section{Zahrotun Hanifah, Suparno, Slamet Supriyadi}

Master Degree of English Education Department Universitas Sebelas Maret, Surakarta, Indonesia

Email corresponding author: zahrotunhanifah76@gmail.com

How to cite this paper: Hanifah, Z., Suparno, \& Supriyadi, S. (2019). Implementing Collaborative Writing to Teach Writing for Non-English Major Students. International Journal of Language Teaching and Education, 3(2), 142-157. https://doi.org/10.22437/ijolte.v3i2.7907

Accepted: November 25, 2019

Published: December 31, 2019

Copyright $\odot 2019$ International Journal of Language Teaching and Education

This work is licensed under the Creative Commons Attribution International License (CC BY 4.0). http://creativecommons.org/licenses by $/ 4.0 /$

(c) (i)

\begin{abstract}
This study aims to expose and explore the implementation of collaborative writing in a non-English department in a state university in Surakarta, Indonesia. The method used in this study was descriptive qualitative focusing on the procedures of collaborative writing. The participants of the study were 63 students who were then divided into 16 groups for their collaborative project. In collecting the data, the researcher conducted document analysis, observations, and interview with both the lecturer and students. Three students were selected purposively for interview. The findings of this study were specific procedures of collaborative writing for non-English major students and different types of collaborative writing strategy applied by students. The procedures of collaborative writing for non-English major students comprised forming group, determining topic, outlining, drafting, editing and revising, and submitting. Meanwhile, the strategies applied by students in collaborative writing were reactive writing and parallel writing. In the implementation of collaborative writing, students also faced some difficulties. Those are in terms of cooperation between group members, irresponsible group members, and active learning. In implementing collaborative writing especially for non-English major students, it is better for teachers to consider the language proficiency of the students. In addition, teachers' guidance is very important in the process of collaborative writing for non-English major students.
\end{abstract}

\section{Subject Areas}

Writing

Keywords

Collaborative Writing, Non-English Major Students, Teaching Writing

\section{Introduction}

Collaborative learning has been popular among English teaching practitioners. Collaborative learning has been widely implemented by teacher in their classroom and become a hot subject for researchers to study. The underlying theory of collaborative learning is Vygotsky's social development theory. The 
Zahrotun Hanifah, Suparno, Slamet Supriyadi

theory explains that learning is a social process and is therefore enhanced through social interaction(Utami, 2012). Thus, students learn new thoughts and processes through social contacts that boosts their development (Utami, 2012). The term "collaborative" in "collaborative learning" means students team up with their peers in a group consisting at least two students to share understanding and language resources, to negotiate with their peers, in order to create a joint product (Widodo, 2013).

Recently, collaborative writing is widely used by many teachers in their writing class due to its significances that have been investigated through some conducted researches. First, it is proved that collaborative writing can give significant development on students' writing compared to individual writing (Elola, I., Oskoz, 2010). Second, collaborative writing has been also proved to improve the writing aspects such as writing accuracy, fluency, complexity (Mehrdad and Alavi, 2016), grammar accuracy (Shahgoli and Farrokhi, 2016), and vocabulary acquisition (Bakhshayesha, 2016). In addition, collaborative writing is suitable to improve not only for one certain type of writing. It is proved that collaborative writing can improve students' academic writing (Luna, A., Ortiz, 2013), descriptive writing (Supiani, 2012), summary writing (Lin and Maarof, 2013), and report writing (Fong, 2012). Last but not least, in the implementation of collaborative writing, it is possible for teachers to elaborate it with other teaching media such as the use of Google Docs (Suwantarathip, O. and Wichadee, 2014), Wikis (Hadjerrouit, 2011), and Website (Kessler, G., Bikowski, D., Boggs, 2012).

Meanwhile, English writing is not only taught for particular group of students. In fact, it is taught for almost all groups of students in different major and different level that will lead different perceptions towards writing. For English as Foreign Language (EFL) students, English writing is considered as a mean of showing their language proficiency such as vocabulary, grammar, sentence, culture and English thinking pattern while for non-English major students English writing is a part that they will easily fail to get good marks (Xiayou and Hongliang, 2015). Accordingly, the strategy of teaching writing for non-English major students must be different from other group of students.

However, the research investigated the suitable method teach writing for non-English students is remarkably rare to find. Only several studies have investigated strategy to teach writing for non-English students such as a study conducted by Xiayou and Hongliang (2015) and a study conducted by (Ren, 2017). (Xiayou and Hongliang) in their study (2015) found that there is a teaching strategy can be used for writing teacher in teaching writing for non-English major students which is called as micro-writing approach. They proposed that this approach is effective to optimize students' writing compared to other traditional approach of teaching writing. The study conducted by (Ren, 2017) explores an alternative to college teaching learning process of English writing for non-English majors namely teaching writing based on reading under the output-driven, input-enabled hypothesis.

Due to the limited references of teaching writing method for non-English major students, lecturers inevitably apply method commonly used to teach writing for English major students and adapt it to their 
Zahrotun Hanifah, Suparno, Slamet Supriyadi

students who are non-English major students. In fact, not all teaching method for English major students suits for non-English major students. This is due to several factor such as the background of the students, the purpose of English course, and many others. In a non-English department in a state university in Surakarta, there was writing course attended by students.

This course was interesting since it aimed to make students who were non-English major students able to write a journal article in English. Thus, the researcher was interested to conduct pre-lemininary study. From pre-leminary study conducted by the researcher, it was found that the lecturer of the writing course applied collaborative writing. Collaborative writing for non-English major students must be different from that for English major students. Thus, this study aimed to describe the implementation of collaborative writing to teach writing for non-English major students. Specifically, this study focused on collaborative writing procedure and difficulty faced by students.

\section{Literature review}

\subsection{Overview of Collaborative Writing}

The term collaborative writing was firstly emerged from the idea that writing is a social activity. In various social circumstances, people as community's member as well as the writer do such kind of collaboration through writing (Murray, 1992). In the society context, members talk about their letter and notes, asking advice on their writing while in the workplace, managers and others discuss their memos and reports, comment on, add to, and change each other's texts, or delegate their writing to another"(Murray, 1992). This shows that every member of communities collaborate each other to discuss their text and at the same time to create context.

Collaborative writing is defined as a method of writing in which students do not do it individually, rather, they team up with one or more peers to go through the writing process (Luna, A., Ortiz, 2013). It is in line with (Soraya, 2016) who explained that collaborative writing involves two or more students to accomplish an assignment or to complete task. In addition, Bosley (1989) states that collaborative writing deals with two or more people working together to produce a document with group responsibility for the end product.

Since collaborative writing is a group work, sharing responsibility is very essential. Sharing responsibility in collaborative writing itself is built from Vygotski's notion that "social interaction precedes development; consciousness and cognition are the end product of socialization and social behavior" (Heidar, 2016). It means that sharing responsibility in collaborative writing will lead students for development because collaborative writing provides them same opportunity not only to practice literature review, academic reading and writing, but also to stimulate reflection, knowledge sharing, and critical thinking (Heidar, 2016). 
Zahrotun Hanifah, Suparno, Slamet Supriyadi

In the implementation, as other method of writing, collaborative writing has several principles that must be considered by teacher. First, students must be cooperative. Collaborative writing is under the umbrella of cooperative writing (Speck, 2002). Thus, being cooperative is the main key point of collaborative writing. Cooperative means each member must have positive interdependence to each other, support each other's learning, success face to face, hold and believe each other that his teammates is accountable to do his or her fair share of the work, appropriately use the interpersonal and small-group skills needed for cooperative efforts to be successful, and process as a group how effectively members are working together (Johnson in Speck, 2002).

In such cooperation, responsibility of each member is another important point students and teacher must concern in collaborative writing. Sharing responsibility is counted as the second principle in collaborative writing. Storch (in Widodo, 2013) states that in collaborative writing students are jointly responsible for composing a text (Talib, $\mathrm{T}$ and Cheung, 2017) assert that the success of collaborative writing depends on the responsibility that each member takes. In addition, Speck (2002) explains that cooperative learning, in this case is collaborative writing, focuses on students' taking responsibility for their learning by being given classroom opportunities to have authority in learning.

Having authority in learning means students must be active in the learning process. In collaborative writing, students are required to have active learning and sharing they knowledge to their friends ( $\mathrm{Su}$ wantarathip, $\mathrm{O}$ and Wichadee, 2014). They also have the authority to determine their material and to think critically about related issue in their study group. Meanwhile, the teacher/ instructor is no longer viewed as the only agent of knowledge who "deposits" knowledge to the learners (Elola, I and Oskoz, 2010). Active learning is the third principle of collaborative writing.

\subsection{Overview of Non-English Major Students}

Teaching English for non-English major students is a part of teaching English for a specific purposes (ESP) because the teacher should correlate their teaching with the context of students' background. This will be definitely different from teaching English major students/ EFL students due to the different characteristics, needs, and even problems of non-English major students from English major students/ EFL students. As explained by Akhiroh (2017) that "ELT in higher education is based on the need of each university due to university's autonomy to design their own curriculum". This showed that English teaching in University is designed most likely different from one major to another. Thus, it is obvious that there must be a huge different English teaching design between English major and non-English major since each of them has different needs. In addition, language learning strategies of both English major students and non-English major students is also different.

"Language learning strategies may refer to the behaviors and thoughts that learners meta-cognitively, cognitively, affectively, and socially engage in improving their performance in the target language" (Zheng, 2011). (Oxford, 1990) classified language learning strategies into two main classification which 
Zahrotun Hanifah, Suparno, Slamet Supriyadi

are direct strategies and indirect strategies. Each of them is then classified into further classification. Direct strategy covers memory strategies, cognitive strategies, compensation strategies while indirect strategy covers metacognitive strategies, affective strategies, and social strategies. Zheng (2011) in his research explains that there are different preferences of learning strategies between English major students and non-English major students. He found that for English major students, the rank order of students' preference among the six strategies are compensation strategies, metacognitive strategies, cognitive strategies, social strategies, affective strategies, and memory strategies. Meanwhile, non-English major students adopt the strategies in the following rank order: memory strategies, compensation strategies, metacognitive strategies, cognitive strategies, affective strategies, and social strategies.

Considering the difference learning style of non-English major students as explained above, the qualification of the lecturer and the teaching strategies which are applied are the main keys of the success of ELT for non-English major students. As Akhiroh (2017) asserts that the main problem of English teaching for non-English major students depends on the availability of qualified English lecturer. It is suggested for non-English major to hire lecturer having education background of English language teaching. Secondly, teaching strategy applied by the lecturer also plays important role in ELT for non-English major student. Exley (2005) specifies that most Indonesian students are categorized as less than good in spoken and written English proficiency. This may be because non-English department students are not taught how to learn English with appropriate teaching strategies (Setiyadi, 2001). In addition, Sulistiyo (2016) explained that teaching English in Indonesia especially for non-English major students is less effective due to some aspects. Those aspects are "teacher qualifications and low English proficiency, classroom size, students' motivation, classroom-oriented learning, and limited sources of learning”.

\section{Method}

The method of this study was case study. The setting of this study was the Academic Writing course of a non-English department in a state university in Surakarta. Teaching and learning process in the classroom was the object of this research. In addition, three second semester students and the lecturer of the Academic Writing course were involved as the participants. Three students were selected using purposive sampling technique. Furthermore, some teaching documents were also used to collect the data.

In collecting the data, the researcher applied several techniques namely observation, document analysis, and interview. The researcher applied a series of non-participatory observations to reveal how collaborative writing was implemented. The observations were conducted while the teaching learning process is ongoing. Observations were done in six class meetings. Furthermore, semi-structured interviews were conducted to both students and the lecturer. The interviews were done to seek information dealing with the difficulty faced by students in the implementation of collaborative writing.

Checking the credibility of the data being collected is necessary. Trustworthiness is one of many ways to strenghten the credibility of qualitative research. To stenghten the credibility of the research, 
Zahrotun Hanifah, Suparno, Slamet Supriyadi

there are some sstrategies can be applied by the researcher. Creswell (2012, p. 259) proposes three primary strategies to enhance the accuracy or credibility of the research findings namely triangulation, member checking, and external audit. Regarding the objective of the study, method of triangulation was used. In this study, the researcher conducted data triangulation and methodological triangullation. In data triangulation, data is assumed as valid data if they are collected from different sources (Patton, 2002, in Yin, 2016, p. 87). In this study, some different sources of data were used in order to answer one research questions. They were events, the lecturer, students, and document. Meanwhile, in methodological triangulation, the research compared the data obtained from different tecniques: observations, interview, and document analysis. The data which were in the form of information were then analyzed and presented in a descriptive writing.

\section{Result}

This study investigates how collaborative writing is implemented in Academic Writing course for nonEnglish major students. This study focuses to explore the procedure of collaborative writing, the students' difficulties in collaborative writing, and lecturer's role in collaborative writing

The Academic Writing course where this study was conducted was attended by 63 students who were non-English Department students. Based on the syllabus used by the lecturer, it was found that the lecturer designed non-Writing activities in the first seven meetings. When the lecturer was asked the reason, he answered as the following comments:

"when you teach writing especially academic writing for non-English majors, you cannot go directly to writing. Willy nilly, you must start it with general English like grammar, then you can go to writing activity. However, you must start it from the simplest one such as mechanics, making sentences, making paragraphs, making essays, then articles" (letcurer ARF)

From the transcript above, it is found that the lecturer tried to adjust the Academic Writing course to the students' background who were non-English major students. This aimed to facilitate students in mastering the materials and skills needed in writing their collaborative projects. The project of the collaborative writing was writing a journal article. Actually, the collaborative writing was started at the fifth meeting by forming group. However, the writing activity was started at the tenth meeting and was done within 4 meetings starting at the tenth meeting to the thirteenth meeting.

\subsection{The Procedure of Collaborative Writing}

As other method of writing collaborative writing also has certain procedure must be followed by the writers. This study resulted at a specific procedure of collaborative writing done by students in Academic Writing course of a non-English major department in a state university in Surakarta. The following are the description of each stage of the procedure:

Forming Group 
Zahrotun Hanifah, Suparno, Slamet Supriyadi

Forming group is the first step of collaborative writing procedure. In forming group, the class which consisted of 63 students was divided into 16 groups. Among 16 groups, 15 groups consisted of 4 members while the rest consisted of only 3 members. In forming group, students had full authority to choose the member of the group. The lecturer assumed that by giving full authority in choosing the members to the students, students could choose with whom they were comfortable to work with. As result, the collaboration in doing project would run smoothly.

\section{Discussing the Interest}

After forming group, the students discussed the topic for their collaborative writing project. The topic should relate to their Department. In discussing their interest, most groups let their member to express their opinion one by one. Besides, there were also groups that only follow the ideas of one or several students due to the domination of certain students in the group. The discussion took place inside and outside classroom. After choosing the topic, they consulted to the lecturer for feedbacks, suggestions, or alternative topics. After the lecturer gave feedback to the topic they chose, they continued the process of collaborative writing that were outlining and drafting.

\section{Outlining and Drafting}

Before starting drafting, students discussed with their group to make outline. Outlining could be described as making framework of their writing. After outlining, the students started the drafting process. Drafting was the follow up activity for the outline that had been created. In drafting, there were some different strategies applied by the groups. Some groups wrote the article together from the beginning to the end.

On the contrary, some other groups preferred to divide tasks to each group member. There were some reasons underlying the selection of the drafting strategies. Those who committed to do it together from the beginning till the end of the article assumed that this strategy would give them more benefits in writing because it involved all members in all parts of the article writing so that this allowed students to learn what was discussed and written in each part of the article.

However, this strategy was considered less effective because the members needed to meet face to face. Besides, it was also time consuming. Meanwhile, for those who divided tasks to each group member found it more effective and less time consuming. While drafting, the lecturer welcomed students for some consultations.

In this stage, the students not only wrote down their ideas but also did some literature studies to the references or theory that were relevant with their writing. This aimed at strengthening their ideas. Since it was done collaboratively, students also experienced debates and conflicts with one another. On the other hand, in groups that were dominated by certain students made other members in the group dependent and did not do their job well. 
Zahrotun Hanifah, Suparno, Slamet Supriyadi

Editing

After finishing the drafting process, the next step of collaborative writing was editing. In the editing process, almost all groups did peer-correction. In this stage, students checked and corrected their teammates' work to find any errors that possibly occurred intentionally or not in the process of writing such as misspelling, grammar, mechanic, and other mistakes related to the content of their writing. In some groups, peer-correction was done involving all members of the group. Meanwhile, in some other group, peer-correction was done only by one to two members who had better English proficiency.

\section{Submitting}

The final step of collaborative writing was submitting. Before submitting, all groups made sure that their articles were ready to be submitted to the lecturer. Thus, before submitting, all group made last review on their article. Submission was done by sending the final article to the lecturer by email.

\subsection{The Difficulties of the Students}

As other method of writing, all groups faced several difficulties in the process of collaborative writing. Based on the interviews with the students, the difficulties that students faced were their cooperative, the irresponsible member, and members who did not role active learning. The following are the description of each term.

\section{Cooperation among Group Members}

Being cooperative means that each member of the group must have positive independence to each other, support each other's learning, and process as a group to effectively working together. Based on the observation, it was found that members in all groups worked cooperatively. This could be seen from how the members discussed to determine the topic that would be the topic of their writing and took part in the writing process. However, based on interviews conducted, there were several groups whose members were not cooperative because they tended to be passive that they did not do their task in the writing process and depend on other members. The following is the explanation of the student:

"The main problem that my group faced was two members in my group were not willing to cooperate at all. Automatically, I and my only one teammate were burdened since we had to finish the article ourselves". (student $A$ )

From the transcript above, it can be inferred that the bad cooperation among members became the major obstacle for the groups in finishing their writing. Nevertheless, the cooperation of the class that the researcher observed was considered good because from 16 groups there were only about 4 groups that had the problem stated above. In addition, out of 63 students only about 11 students were not cooperative. In other words, the cooperative level of students in this class is $81.7 \%$.

\section{Irresponsible Member}

From both observation and interview with the students, the researcher found that all groups shared 
Zahrotun Hanifah, Suparno, Slamet Supriyadi

responsibility with the member. The responsibility sharing was based on the level of English proficiency possessed by each member. Members with high English proficiency took over the introduction and discussion sections. Meanwhile, members with low-medium English proficiency worked on literature review and methodology sections. However, not all of students committed to do the responsibility they had. Several students were irresponsible with their job. They did not finish their work on time. Even some students did not do their part at all so that their teammates doing their parts help.

\section{Active Learning}

Being active in the learning process let the students to grow their own authority to share, acquire knowledge and solve any problems in the learning process in a team. The collaborative writing process was considered as student-centered learning which requires students to be active during the learning process. Based on the observation, students experienced active learning during the collaborative writing process. It is showed from the authority that students had to choose with whom they will write, what to write, how to write, what is need to support their writing, how to collect theory, data, references that is needed for their writing, how they cope the problem they faced during writing, and many others. Although this seemed positive for students, this created other difficulties for the students.

As non-English major students, letting them to write independently was not a good idea. Some students revealed that writing was not their habit. Thus, it was difficult for them to do the writing process from the beginning till the last step. Moreover, their project was writing a journal article in English that they never did it before. Dealing with the academic vocabulary and content of writing were the problems arising from being in active learning. Even though the collaborative writing process depended on students as the center of learning, this did not mean that students did not need the lecturer in this process. As non-English Major students, lecturer's guidance is needed.

\subsection{The Role of the Lecturer in the Classroom}

Based on observations and interviews, lecturers have a dual role as sources of knowledge, and as facilitator. This might sound ambiguous because as is known collaborative writing is student-centered learning and the teacher does not act as a source of knowledge. As stated above, lecturers were no longer of the source of knowledge (Elola, I and Oskoz, 2010). The following is some part of interview with the lecturer. However, as it is well known, the students participating in this study were not students majoring in English and their job was to write a journal article in English. Thus, lecturers play an important role as sources of knowledge related to the use of English in their writing. The following is some part of interview with the lecturer.

"Actually the only thing really needed for them is guidance in their writing activities. They are indeed included in the medium-advanced English group. But they are not accustomed to using it in writing especially writing journal articles. Often the language they use is spoken language rather than written. Even though, this is writing. So in this case I became a kind of proof reader and also a source of 
Zahrotun Hanifah, Suparno, Slamet Supriyadi

language knowledge for them. So, their questions are mostly related to linguistic problems. If there is not a lot of content, references, discussions, or things about their writing. Yes there are some who ask, but not many. They are already very independent with the ideas of their writing." (lecturer ARF)

In this process, the lecturer became facilitator for the students. The lecturer provided students some links of journal access that may help them to find references for their writing. For those who could not find any related references, the lecturer helped them by giving them suggestion about closest related topic that they can find it from journal. The finding of this study showed there was a specific procedure students must take in collaborative writing activities.

To sum up, the finding of this research resulted at several findings. First, it resulted at a specific procedure of collabrative writing. From the research finding, it is showed that the procedure of collaborative writing compries several steps namely forming group, discussing the interest, outlining and drafting, editing, and submitting. Barkley (2005) proposes seven steps of collaborative writing which are forming team and then genereating ideas, organizing ideas and creating outline, individual drafting by dividing up the outline for each student, doing peer correction, compling individual section into a single documen, revising and editing, submitting the paper to the professor. In addition, Widodo (2013) breaks down the procedure of collaborative writing into nine stages. Those are forming group, teacher scaffolding, collaborative idea generating, drafting, giving feedback, editing, revising, submitting and assessment by the teacher. There was a gap between research finding and collaborative writing theory in term of collaborative writing procedure. The gap was that there were some stages from collaborative writing theory which were not applied. The gap might be caused by several factors. One of them as the main factor was students who are not majoring in English. Thus, the lecturer must adjust the procedures to the background of students. For example, in the theory proposed by Barkley (2005), the stage namely peer-correction will be easily carried out by English major students. However, it will be a big deal for non-English major students to carry out. In addition, the limited time is also the basic factor why the collaborative writing procedure applied differs from the theory.

Adjusting the learning process to the students' backround is worth to consider by all teachers and lecturers. As stated by Mulyasa (2007) that teaching-learning material should be adjusted based on the needs and abilities of the students, containing the value of the functional, practical, and adapted learning materials to the conditions and needs of environment, school, and region. The learning needs of students include everything that students need to do when learning the language in the course, such as subjects they want to explore, input texts they want to receive, learning strategies, learning tasks, learning media, task styles and evaluation methods they prefer (Jamilah, 2016). In line with Akhiroh (2017), English language teaching in the higher education is based on the need of the department, so it needs specific curriculum differs from English majoring students called English for specific purposes (ESP). In addition, different learning strategies between English major students and non-English major students is also 
Zahrotun Hanifah, Suparno, Slamet Supriyadi

considered by teachers and lecturers in dsigning their course. As stated by Zheng (2015) in his research that non-English major students apply different learning strategies from those of English major students.

Secondly, in the drafting process, it was found that the groups used different strategy of collaborative writing. The first strategy employed all member of the group to get actively involved in every part of the writing from beginning until finished.This strategy is called as reactive writing. It occurs when team members collaborate synchronously to develop their product (Lowry, et al, 2007). Meanwhile, the second strategy divided up the article into several parts and assigning each member to work on different parts. This strategy is called as parallel writing. Parallel writing occurs when a team divides collaborative writing work into discrete units and works in parallel (Lowry, et al, 2007).

Third, in term of difficulty faced by students in the implementation of collaborative writing, it was explained that difficulties faced by students were in term of cooperation among group members, irresponsible members, and active learning. From the research finding, it is stated that the bad cooperation among members became a big obstacle for students to finish their writing. In fact, cooperation is the main principle of collaborative writing. To cooperate, a group must have clear positive interdependence and members must promote each other's learning and success face to face, hold each other individually accountable to do his or her fair share of the work, appropriately use the interpersonal and small-group skills needed for cooperative efforts to be successful, and process as a group how effectively members are working together (Johnson, Johnson, and Smith in Speck, 2002: 8). Thus, if the cooperation between group members does not go well, other problems in collaborative writing cannot be avoided to arise.

Collaborative writing means that students are jointly responsible for composing a text (Storch in Widodo, 2013). Thus, being responsible in the process of colaborative writing is a must for each member of the groups. The second dificulty faced by students was there were irresponsible members in their group. The irresponsible members automatically influence the writing process since the success of colaborative writing depends on responsibility that each member takes on (Talib and Cheung, 2017). There were many factors underlying the irresponsible students. Chilsom(1990) argues that students become irresponsible in collaborative writing because they tend to place low priority on a collaborative writing project that they are unwilling to invest their time and effort that a group project requires.

Collaborative writing is a method which highly promote students to have active learning. Based on the research finding presented before, it is stated that students faced difficulty in active learning. Since the students were non-English major students, doing collaborative writing from the beginning till the last step was difficult for them especially in writing an academic writing. Academic writing requires students to have a good knowledge of grammar, syntax, spelling, vocabulary, and others (Alameddine and Mirza, 2016). Thus, it is not questionable if the students also faced difficulty in language elements 
Zahrotun Hanifah, Suparno, Slamet Supriyadi

such as grammar and vocabulary. As stated by $\mathrm{Hu}$ (2014) that although non-English major students have a large enough vocabulary, they tend to fail to express their ideas freely and clearly.

Collaborative learning in terms of learning writing needs good preparation and planning because several stages determine the next learning activities and students' learning achievements. This course was prepared well by the lecturer. He regarded his students as non-English major so he tended to give an introduction to English in general. As stated by Akhiroh (2017), English language teaching in the higher education is based on the need of the department, so it needs specific curriculum differs from English majoring students called English for specific purposes (ESP). This stage is very crucial before going with academic English writing. As we know, academic English writing is course which needed a higher understanding in English grammar, structure, and text. Moreover the students here were non-English major so they need extra time to understand English basic rules

The learning process stages from forming the group, discussing interested topics, drafting, peer correction, lecture's feedback, revising, submitting, and play important role in developing students' awareness in writing academic English. It was proofed from 63 students divided into 16 groups, there were just only four groups which did not run the collaborative learning activities well. It means, there was more than $80 \%$ students in this course achieve their collaborative skills. Although there were some weaknesses as domination in group, grammar accuracy and vocabularies building, this process of learning showed significance for students' achievements in their academic English writing projects. This was because lecturers or teachers nowadays were no longer as the source of knowledge, they are just become facilitators who facilitate, stimulate, and motivate the students to achieve great achievements (Elola, I and Oskoz, 2010)

Three basics principles of collaborative learning were implemented well in this course. More than $80 \%, 11$ Groups from 15 groups were doing well the cooperative works with their friends. Then, students experienced active learning during the collaborative writing process. It is showed from the authority that students had to choose with whom they will write, what to write, how to write, what is need to support their writing, how to collect theory, data, references that is needed for their writing. The last, because of this course was a non-English major course, for the sharing responsibility, this is just only dominated by students with high proficiency in English. That's no problem because their friends were able to study accuracy, vocabulary building, complexity, pronunciation, etc. from them.

\section{Conclusion}

The collaborative writing process was considered as student-centered learning which requires students to be active during the learning process. Students experienced active learning during their collaborative writing process. It is showed from the authority that students had to choose with whom they will write, what to write, how to write, what is need to support their writing, how to collect theory, data, references that is needed for their writing, how they cope the problem they faced during writing, and many others. 
Zahrotun Hanifah, Suparno, Slamet Supriyadi

Even though the collaborative writing process depends on students as the center of learning, this does not mean that students do not need lecturers in this process. As non-English Major students, lecturer's guidance is needed.

Dealing with English proficiency, it also let the group domination. In stages of sharing, group members with higher English proficiency take over the introduction and discussion sections. Meanwhile, members with low-medium English proficiency work on literature review and methodology sections. However, not all of students committed with their responsibility. As explained above, some students were not cooperative in the process of learning.

All the principles of collaborative writing such as students' cooperative work, sharing responsibility, active learning by having their authority to determine what material should be discussed, shared, and thought critically to their friends and also their involvement on the learning process showed they participated actively in this course. From 63 students who divided into 16 groups, there were 11 groups succeeded in doing cooperative work with their friends. It means, that was around $81.7 \%$ students achieved it. 4 groups left did not run the activities well. Although there were $18.3 \%$ students do not run the activities well, it can be concluded that the collaborative writing in this course was successful.

\section{References}

[1] Akhiroh, N. (2017). Teaching English in non-English Departments: Empowering Teacher towards Improvement. Indonesian Journal of English Education, 4(1), 49-62. doi: 10.15408/ijee.v4i1.5341

[2] Alameddine, M., Mirza, H. (2016, April). Teaching Academic Writing for Advanced Level Grade 10 English. Paper presented at the International Conference on Teaching and Learning English as an Additional Language, Antalya, Turkey. Retrieved from https://doi.org/10.1016/j.sbspro.2016.10.048. doi: 10.1016/j.sbspro.2016.10.048

[3] Bakhshayesha, E. (2016). The Contrary Effect of Collaborative Writing on ESL students vocabulary acquisition. Sociology Journal, 6(3), 196-203. doi: 10.17265/2159-5526/2016.03.005

[4] Barkely, E., Cross, K., Major, C. (2005). Collaborative Learning Techniques: A Handbook for College Faculty. San Fransisco: Jossey-Bass.Bosley, D. (1989). A national study of the uses of collaborative writing in business communications courses among members of the ABC. (Unpublished dissertation). Illinois State University, Illinois, USA.

[5] Chisholm, R. M. (1990). Coping with the problems of collaborative writing. The Writing Across the Curriculum Journal, 2, 90-108. Retrieved from http://wac.colostate.edu/journal/

[6] Elola, I., Oskoz, A. (2010). No Collaborative Writing: Fostering Language and Writing Conventions Development. Language Learning \& Technology Journal. 14(3), 51-71. doi: 10125/44226 
Zahrotun Hanifah, Suparno, Slamet Supriyadi

[7] Exley, B. E. (2005). Teachers' professional knowledge bases for offshore education: Two case studies of western teachers working in Indonesia. (Doctoral dissertation, Queensland University of Technology, Brisbane, Australia). Retrieved from https://eprints.qut.edu.au/16021/1/Beryl_Exley Thesis.pdf.

[8] Fong, L. (2012). Benefits of Collaborative Writing for ESL Advanced Diploma Students in the Production of Reports. Retrieved from ERIC database (ED533571).Hadjerrouit, S. (2011). A collaborative writing approach to wikis: Design, implementation, and evaluation. Issues in Informing Science and Information Technology, 8, 431-449. Retrieved from http://iisit.org/Vol8/IISITv8p431-449Hadjerrouit224.pdf.

[9] Heidar, D. M. (2016). ZPD-assisted Intervention via Web 2.0 and Listening Comprehension Ability. English for Specific Purposes World, 17(4), 1-17. Retrieved from http://www.esp-world.info/Articles 49/Heidar.pdf.

[10] Hu, Zhenwen. (2014). Error Analysis of the Non-English Majors' English Writings and the Countermeasures in College English Teaching in Newly-built Undergraduate University. Proceeding of the 3rd International Conference on Science and Social Research, 560-565. doi: https://doi.org/10.2991/icssr-14.2014.128

[11]Jamilah. (2016). English Learning Needs of Non-English Major Students Of Higher Education. In Budiyanto, C., Widiastuti, I., Zainuri, H., Kurniawan, H., \& Kamal, F (Eds). Proceeding of the 2nd International Conference on Teacher Training and Education, 2, 683-689. doi: https://doi.org/10.20961/ictte.v2i1

[12]Kessler, G., Bikowski, D., Boggs, J. (2012). Colaborative Writing among Second Language Learners in Academic Web-based Projects. Language Learning \& Technology. Language Learning and Technology, 16(1), 91-109. doi: 10125/44276

[13]Lin and Maarof. (2013). Collaborative Writing in Summary Writing: Student Perception and Problems. Paper presented at the 6th International Conference on University Learning and Teaching(InCULT 2012). Procedia, 90, 599-606. doi: 10.1016/j.sbspro.2013.07.131

[14]Lowry, Paul B., Curtis, A., Lowry, Michelle R. (2004). Building Taxonomy and Nomenclature of Collaborative Writing to Improve Interdisciplinary Research and Practice. Journal of Bussiness Communication, 41(1): 66-99. doi: 10.1177/0021943603259363

[15]Luna, A., Ortiz, L. (2013). Collaborative Writing to Enhance Academic Writing Development Through Project Work. HOW Journal, 20(1), 130-148. Retrieved from https://www.howjournalcolombia.org/index.php/how/article/view/27

[16] Mehrdad A., Alavi, S., Khatib, M. (2016). The Effect of Collaborative Writing Practice on EFL Learners' Writing Accuracy, Complexity, and Fluency. Modern Journal of Language Teaching Method, 6(1), 285-296. 
Zahrotun Hanifah, Suparno, Slamet Supriyadi

[17]Mulyasa, E. (2007). Kurikulum Tingkat Satuan Pendidikan: Sebuah Panduan Praktis. Bandung: Remaja Rosdakarya.

[18] Murray. (1992). Collaborative Learning As Literacy Event : Implication for ESL Instruction. England: Cambridge University Press.

[19]Oxford, R. . (1990). Language Learning Strategies: What every teacher should know. New York: Newbury House.

[20]Ren, J. (2017). College English Writing Instruction for Non-English Majors in Mainland China : The Output-Driven , Input Enabled" Hypothesis Perspective. English Language Teaching, 10(7), 150157. doi: 10.5539/elt.v10n7p150

[21]Setiyadi, B. (2001). Language Learning Strategies: Classification and Pedagogical Implication. TEFLIN Journal, 12(1), 15-28. doi: http://dx.doi.org/10.15639/teflinjournal.v12i1/15-28

[22] Shahgoli and Farrokhi. (2016). The Effect of Individualization Versus Collaboration on the Accuracy of Written Grammar. Modern Journal of Language Teaching Methods, 6(5), 356-371.

[23] Soraya, K. (2016). The Effectiveness of Collaborative Writing Strategy (CWS) in Writing Lesson Regarded to the Students' Creativity. Lingua Cultura, 10(2), 63-67. doi: https://doi.org/10.21512/lc.v10i2.898

[24]Speck, B. (2002). Facilitating Students' Collaborative Writing. New York: John Wiley \& Sons.

[25] Sulistiyo, U. (2016). Learning English As a Foreign Language In An Indonesian University: A Study of Non- English Department Students' Preferred Activities Inside and Outside the Classroom. Indonesian Journal of English Teaching, 5(1), 1-26. doi: https://doi.org/10.15642/ijet2.2016.5.1.1-26

[26]Supiani. (2012). Improving the Student's Ability in Writing Descriptive Texts Through Collaborative Writing Technique. Journal of English as a Foreign Language, 2(2), 11-20. Retrieved from https://pdfs.semanticscholar.org/569c/721435d5b35041ff55f79913bdb712cf6fe0.pdf

[27] Suwantarathip, O., Wichadee, S. (2014). The Effect of Collaborative Writing Activity using Google Doc on Students' Writing Abilities. The Turkish Online Journal of Educational Technology 13(2), 148-156. Retrieved from ERIC database (EJ1022935)

[28] Talib, T., Cheung, Y. (2017). Collaborative Writing in Classroom Instruction: A Synthesis of Recent Research. The English Teacher, 46(2), 43-57. Retrieved from https://www.researchgate.net/publication/319930154 Collaborative Writing in Classroom Instruction A Synthesis of Recent Research

[29]Utami, A. B. (2012). Improving Students' Writing Skill on Recount Texts Through Collaborative Writing Technique (A Bachelor Thesis, Universitas Negeri Yogyakarta, Yogyakarta, Indonesia). Retrieved from https://eprints.uny.ac.id/38716/1/Amrih\%20Bekti\%20Utami 07202244062.pdf

[30]Widodo, H. (2013). Implementing Collaborative Process Based Writing in the EFL College Classroom. Research Papers in Language Teaching and Learning. 4(1), 198-206. 
Zahrotun Hanifah, Suparno, Slamet Supriyadi

[31]Xiayou and Hongliang. (2015). A Study of Optimizing Non-English Majors' English Writing Teaching Approach Through Micro Writing. 11(6), 25-29.

[32]Zheng, S. (2011). New Horizon College English (Second Edition): Reading and Writing. Beijing: Foreign Language Teaching and Research Press.

[33]Zheng, Ling. (2015). Research on English Learning Strategies Between English Major and NonEnglish Major Students. US-China Foreign Language, 13(10), 706-709. 